\title{
Role of mesenchymal liver cells in mediating hepatic toxicity and carcinogenesis
}

\author{
Sandra Sagmeister, Wolfram Parzefall, Christine Gauglhofer, \\ Christopher Gerner, Rolf Schulte-Hermann and Bettina Grasl-Kraupp*
}

\author{
Address: Department of Medicine I, Institute of Cancer Research, Medical University of Vienna, Austria \\ Email: Bettina Grasl-Kraupp* - bettina.grasl-kraupp@meduniwien.ac.at \\ * Corresponding author
}

\author{
from I 3th Scientific Symposium of the Austrian Pharmacological Society (APHAR). Joint Meeting with the Austrian Society of Toxicology (ASTOX) and the \\ Hungarian Society for Experimental and Clinical Pharmacology (MFT) \\ Vienna, Austria. 22-24 November 2007 \\ Published: 14 November 2007 \\ BMC Pharmacology 2007, 7(Suppl 2):A58 doi:10.1 I86/147|-22। 0-7-S2-A58
}

This abstract is available from: http://www.biomedcentral.com/I47I-22/0/7/S2/A58

(c) 2007 Sagmeister et al; licensee BioMed Central Ltd.

Mesenchymal liver cells (Kupffer cells, KC; sinusendothelial cells, EC) are considered to play a role in the response of the liver to pro-inflammatory stimuli. We studied whether genotoxic and non-genotxic carcinogens are also capable to activate these mesenchymal liver cells. Liver cell suspensions were separated into hepatocytes, KC and EC. Cells were incubated with lipopolysaccharid (LPS), the genotoxic N-nitrosomorpholine (NNM) or non-genotoxic carcinogens like nafenopin, cyproterone acetate, phenobarbital, or arsenic. LPS and NNM incuced a release of TNF- $\alpha$ and superoxide while the other compounds showed mostly minor effects on KC and EC. To assess the impact of activated mesenchymal cells on hepatocarcinogenesis a co-culture model of unaltered and preneoplastic hepatocytes was used. DNA synthesis was significantly higher in preneoplastic than unaltered cells and was further increased by supernatant of LPS-stimulated KC and EC. The supernatant effect was greatly abrogated by antisera neutralizing heparin-binding epidermal growth factor-like growth factor (HB-EGF). HB-EGF itself was a potent inducer of DNA synthesis and mitosis preferentially in the preneoplastic hepatocytes. In conclusion, $\mathrm{KC}$ and EC, activated by pro-inflammatory stimuli, may contribute to carcinogenesis via release of growth factors for preneoplastic hepatocytes. Whether this cell activation may be caused by non-genotoxic carcinogens requires further investigations. 